\title{
АНАТОМІЧНІ ВАРІАНТИ БУДОВИ НОСОВОЇ ПОРОЖНИНИ І НАВКОЛОНОСОВИХ ПАЗУХ У ХВОРИХ НА ХРОНІЧНІ СИНУСИТИ
}

Вищий державний навчальний заклад України «Буковинський державний медичний університет», м. Чернівці

Резюме. Проведений аналіз результатів комп’ютерної томографії навколоносових синусів у 84 хворих на хронічний ексудативний синусит, 72 - на хронічний поліпозний синусит. Контрольна група складалася з 20 практично здорових осіб. Анатомічні особливості будови носової порожнини і навколоносових пазух (клітини Галера, перегородки верхньощелепних синусів, зміни гачкоподібного відростка, викривлення носової перегородки) виявлені у 63,89 \% обстежуваних. Жоден з ана-

Вступ. Вивчення аспектів розвитку хронічних захворювань носової порожнини (НП) і навколоносових пазух (ННП) досі не втратило своєї актуальності з огляду на широку розповсюдженість і зростаючу захворюваність [3].

Оскільки для ефективного функціонування ННП надзвичайно важливим є прохідність природних отворів синусів, оптимальний повітрообмін між ННП і НП, вільне носове дихання [5], потенційними чинниками ризику розвитку хронічних синуситів (XC) можуть бути анатомічні варіанти розвитку НП і ННП, які змінюють аеродинаміку НП і сповільнюють дренаж з ННП [7].

Мета дослідження. Визначити частоту зустрічальності анатомічних варіантів будови НП і ННП і визначення їх ролі як чинників ризику розвитку хронічного запального процесу в ННП.

Матеріал і методи. Обстежено 216 осіб дорослого віку, розподілених на три групи. Першу групу склали 84 хворих на хронічний ексудативний синусит (ХЕС); другу - 72 пацієнти 3 хронічним поліпозним синуситом (ХПС); третю (контрольну) групу - 20 осіб із відсутністю анамнестичних вказівок на захворювання НП і ННП. Критерієм виключення $з$ дослідження були перенесені в минулому оперативні втручання на НП і ННП.

Всім хворим проведено комп'ютерну томографію (КТ) ННП. При оцінці результатів КТ визначали стан верхньощелепних, лобових, сфеноїдальних пазух, окремо передніх і задніх решіток на кожному боці за шкалою Lund-Mackay, визначався стан остіомеатального комплексу 3 кожного боку [4]. Окремо вивчалися анатомічні варіації будови ННП: наявність клітин Галера та перегородок верхньощелепних пазух, варіанти розвитку гачкоподібного відростка (його гіпертрофія, подвоєння, аномальне викривлення), надлишкова пневматизація середньої носової раковини (concha bullosa), розвиток лобової і клиноподібної пазух. Викривлення носової перегородки оцінювали за класифікацією R.Mladina [6].

Статистична обробка отриманих результатів проводилася за допомогою програми «Statistica 6» iз визначенням непараметричного $\mathrm{c}^{2}$ [2]. Ідентифікація досліджуваного показника як маркера ризику

() С.А. Левицька, 2015 томічних варіантів не збільшував ризику розвитку поліпозного синуситу. Клітини Галера (RR-2,45; 95 \% CI1,16-3,74), перегородки верхньощелепних пазух (RR-3; $95 \%$ CI-1,72-4,28), аномалія розвитку гачкоподібного відростка (RR-3б17; 95 \% С-1,62-4,72) збільшували ризик розвитку хронічного ексудативного синуситу.

Ключові слова: хронічні синусити, чинники ризику, анатомічні особливості.

оцінювалася методами клінічної епідеміології за результатами обчислення відношення шансів [1].

Результати дослідження та їх обговорення. Середній вік досліджуваних склав $(35,09 \pm 0,77)$ років, у гендерному співвідношенні переважали чоловіки: 69 (54,76 \%) проти 54 (42,86 \%) жінок.

Рентгенологічні ознаки запалення найчастіше виявляли у верхньощелепному синусі (75\%), рідше - у сфеноїдальному (41,67 \%). Кожен другий обстежуваний мав рентгенологічні ознаки етмоїдиту (табл. 1). Цікавою рентгенологічною знахідкою виявилося затемнення верхньощелепного синусу в кожної четвертої і решітчастих клітин у кожної десятої особи контрольної групи.

Блокування остіомеатального комплексу рентгенологічно підтверджено у 38,10 \% хворих першої і 58,33 \% хворих другої груп (табл. 1).

Загальна сума балів за шкалою Lund-Mackay виявилася найвищою в групі хворих на ХПС $(8,46 \pm 0,62)$, дещо меншою - у хворих на XЕC $(6,40 \pm 0,43$; табл. 1$)$.

Вивчення особливостей розвитку НП і ННС показало, що у 55,56 \% обстежуваних мало місце викривлення носової перегородки, хоча III тип викривлення із потенційним розвитком порушень аеродинамічних процесів у середньому носовому ході діагностовано тільки в 30,56 \% (табл. 2).

Всього анатомічні особливості НП і ННП, котpi можуть викликати порушення повітрообміну i дренування ННП, виявлені у 63,89 \% обстежених. Клітини Галера і перегородки у верхньощелепній пазусі траплялися однаково часто (15,28 \%), дещо рідше виявляли різноманітні варіанти будови гачкоподібного відростка (у 11,11 \%). Кожен четвертий обстежуваний мав надлишкову пневматизацію середньої носової раковини (табл. 2). Майже чверть обстежених мала більше двох анатомічних варіантів будови ННП і НП.

У контрольній групі найчастіше виявляли викривлення носової перегородки (у 45 \%), concha bullosa (у $20 \%$ ), рідше - клітини Галера і перегородки верхньощелепної пазухи (у 10 \%) (табл. 2).

У групі хворих на ХЕС найчастіше діагностували викривлення носової перегородки (у 60,71%), 
Таблиця 1

Результати рентгенологічного дослідження хворих за шкалою Lund-Mackay

\begin{tabular}{|c|c|c|c|c|c|c|}
\hline \multirow{2}{*}{$\begin{array}{c}\text { Групи хво- } \\
\text { рих }\end{array}$} & \multicolumn{4}{|c|}{ Затемнення } & \multirow{2}{*}{ БОК } & \multirow{2}{*}{$\begin{array}{c}\text { Загальна } \\
\text { сума }(\mathrm{M} \pm \mathrm{m})\end{array}$} \\
\hline & ВЩС & ПР & $3 P$ & СФП & & \\
\hline $\begin{array}{c}\text { 1-Хворі на } \\
\text { XEC }(n=84)\end{array}$ & $\begin{array}{c}84(100 \%) \\
1-2^{*} \\
1-3^{*}\end{array}$ & $\begin{array}{c}60(71,43 \%) \\
1-3^{*}\end{array}$ & $\begin{array}{c}51 \\
(60,71 \%) \\
1-2^{*}, \\
1-3^{*} \\
\end{array}$ & $42(50 \%)$ & $32(38,10 \%)$ & $\begin{array}{c}6,40 \pm 0,43 \\
\sigma=2,36 \\
1-3^{*}\end{array}$ \\
\hline $\begin{array}{c}\text { 2-Хворі на } \\
\text { ХПС (n=72) }\end{array}$ & $\begin{array}{c}63(87,5 \%) \\
3-4 *\end{array}$ & $\begin{array}{c}47 \\
(65,27 \%) \\
2-3^{*} \\
\end{array}$ & $\begin{array}{c}50 \\
(69,44 \%) \\
2-3 * \\
\end{array}$ & $\begin{array}{c}48 \\
(66,67 \%)\end{array}$ & $\begin{array}{c}42 \\
(58,33 \%)\end{array}$ & $\begin{array}{c}8,46 \pm 0,62 \\
\sigma=3,02 \\
2-3 *\end{array}$ \\
\hline $\begin{array}{c}\text { 3-Контроль } \\
(\mathrm{n}=60)\end{array}$ & $15(25 \%)$ & $6(10 \%)$ & $6(10 \%)$ & 0 & 0 & $\begin{array}{c}0,56 \pm 0,17 \\
\sigma=0,70\end{array}$ \\
\hline $\begin{array}{l}\text { Всього } \\
(n=216)\end{array}$ & $\begin{array}{c}162 \\
(75 \%)\end{array}$ & $\begin{array}{c}113 \\
(52,31 \%)\end{array}$ & $\begin{array}{c}107 \\
(49,54 \%)\end{array}$ & $\begin{array}{c}90 \\
(41,67 \%)\end{array}$ & $74(34,26 \%)$ & $\begin{array}{c}5,62 \pm 0,45 \\
\sigma=3,85\end{array}$ \\
\hline
\end{tabular}

Примітка. ВЩС - верхньощелепний синус, ПР - передні решітки, ЗД - задні решітки, СФП - сфеноїдальна пазуха, БОК - блок остіомеатального комплексу, * - різниця показників статистично значима, $\sigma$ - середнє квадратичне відхилення

Таблиця 2

Анатомічні варіанти розвитку

\begin{tabular}{|c|c|c|c|c|}
\hline \multirow{2}{*}{$\begin{array}{c}\text { Показник, n (\%), } \\
\text { RR }(95 \% \mathrm{CI})\end{array}$} & \multicolumn{4}{|c|}{ Групи хворих } \\
\hline & $\begin{array}{c}1-\mathrm{XEC} \\
\mathrm{n}=84\end{array}$ & $\begin{array}{c}2-X \Pi C \\
n=72\end{array}$ & $\begin{array}{c}\text { 3-Контроль } \\
\mathrm{n}=60\end{array}$ & $\begin{array}{l}\text { Всього } \\
\mathrm{n}=216\end{array}$ \\
\hline \multirow{2}{*}{ Клітини Галера } & $18(21,43 \%)$ & $\begin{array}{c}9(12,5 \%) \\
1-2^{*}\end{array}$ & $\begin{array}{c}6(10 \%) \\
1-3 *\end{array}$ & $33(15,28 \%)$ \\
\hline & $\begin{array}{c}2,45 \\
(1,16-3,74)\end{array}$ & $\begin{array}{c}1,28 \\
(-0,06-2,66)\end{array}$ & $\begin{array}{c}1,88 \\
(0,62-3,14)\end{array}$ & $\begin{array}{c}2,45 \\
(1,16-3,74)\end{array}$ \\
\hline \multirow{2}{*}{$\begin{array}{c}\text { Перегородка верхньощелепного } \\
\text { синусу }\end{array}$} & $21(25 \%)$ & $\begin{array}{c}6(8,33 \%) \\
1-2 *\end{array}$ & $\begin{array}{c}6(10 \%) \\
1-3 *\end{array}$ & $33(15,28 \%)$ \\
\hline & $\begin{array}{c}3 \\
(1,72-4,28) \\
\end{array}$ & $\begin{array}{c}0,81 \\
(-0,63-2,25) \\
\end{array}$ & $\begin{array}{c}1,88 \\
(0,62-3,14) \\
\end{array}$ & $\begin{array}{c}3 \\
(1,72-4,28) \\
\end{array}$ \\
\hline \multirow{2}{*}{ Гіпогенезія лобного синусу } & $6(7,14 \%)$ & $6(8,33 \%)$ & $3(5 \%)$ & $15(6,94 \%)$ \\
\hline & $\begin{array}{c}1,46 \\
(-0,22-3,14) \\
\end{array}$ & $\begin{array}{c}1,72 \\
(0,03-3,41)\end{array}$ & $\begin{array}{c}1,58 \\
(0,04-3,12) \\
\end{array}$ & $\begin{array}{c}1,46 \\
(-0,22-3,14) \\
\end{array}$ \\
\hline \multirow{2}{*}{$\begin{array}{c}\text { Варіанти розвитку гачкоподібного } \\
\text { відростка }\end{array}$} & $\begin{array}{c}12(14,29 \%) \\
1-3 * \\
\end{array}$ & $\begin{array}{c}9(12,5 \%) \\
2-3 *\end{array}$ & $3(5 \%)$ & $24(11,11 \%)$ \\
\hline & $\begin{array}{c}3,17 \\
(1,62-4,72)\end{array}$ & $\begin{array}{c}2,71 \\
(1,11-4,31)\end{array}$ & $\begin{array}{c}2,96 \\
(1,47-4,45)\end{array}$ & $\begin{array}{c}3,17 \\
(1,62-4,72)\end{array}$ \\
\hline \multirow{2}{*}{ Concha bullosa } & $\begin{array}{c}24(28,57 \%) \\
1-2^{*} \\
\end{array}$ & $\begin{array}{c}21(29,17 \%) \\
2-3^{*} \\
\end{array}$ & $12(20 \%)$ & $57(26,39 \%)$ \\
\hline & $\begin{array}{c}1,6 \\
(0,43-2,77)\end{array}$ & $\begin{array}{c}1,65 \\
(0,47-2,83)\end{array}$ & $\begin{array}{c}1,62 \\
(0,49-2,75)\end{array}$ & $\begin{array}{c}1,6 \\
(0,43-2,77)\end{array}$ \\
\hline \multirow{2}{*}{$\begin{array}{c}\text { Викривлення носової перегородки } \\
\text { (I-VI типи) }\end{array}$} & $51(60,71 \%)$ & $42(58,33 \%)$ & $27(45 \%)$ & $120(55,56 \%)$ \\
\hline & $\begin{array}{c}1,88 \\
(0,76-3)\end{array}$ & $\begin{array}{c}1,71 \\
(0,58-2,84)\end{array}$ & $\begin{array}{c}1,8 \\
(0,71-2,89)\end{array}$ & $\begin{array}{c}1,88 \\
(0,76-3)\end{array}$ \\
\hline \multirow{2}{*}{$\begin{array}{c}\text { Викривлення носової перегородки } \\
\text { (III тип) }\end{array}$} & $33(39,29 \%)$ & $21(29,17 \%)$ & $12(20 \%)$ & $66(30,56 \%)$ \\
\hline & $\begin{array}{c}2,59 \\
(2,44-2,74)\end{array}$ & $\begin{array}{c}1,65 \\
(0,47-2,83)\end{array}$ & $\begin{array}{c}2,12 \\
(0,98-3,26)\end{array}$ & $\begin{array}{c}2,59 \\
(2,44-2,74)\end{array}$ \\
\hline \multirow{2}{*}{ Більше 2 анатомічних варіантів } & $\begin{array}{c}24(28,57 \%) \\
1-2^{*} \\
\end{array}$ & $18(25)$ & $9(15 \%)$ & $51(23,61 \%)$ \\
\hline & $\begin{array}{c}2,27 \\
(1,07-3,47)\end{array}$ & $\begin{array}{c}1,79 \\
(0,57-3,01)\end{array}$ & $\begin{array}{c}2,30 \\
(1,13-3,47)\end{array}$ & $\begin{array}{c}2,27 \\
(1,07-3,47)\end{array}$ \\
\hline
\end{tabular}

Примітка. * - різниця показників статистично значима, RR - показник відношення шансів, 95 \%CI - 95 \% довірчі інтервали показника відношення шансів 
рідше - клітини Галера $(21,43 \%)$ і перегородки (25\%) верхньощелепної пазухи, concha bullosa (у $28,57 \%$ ). Така сама тенденція виявлена і в групі осіб з назальним поліпозом (табл. 2).

Визначення показника відношення шансів дало змогу свідчити, що чинниками ризику розвитку ХC є аномалія розвитку гачкоподібного відростка (RR-2,96; 95 \% CI-1,47-4,45) і наявність більше двох варіантів розвитку НП і НHП (RR-2,30; 95 \% CI-1,13-3,47) (табл. 2).

Ризик розвитку ХЕС збільшується за наявності в пацієнта передумов порушення дренування з верхньощелепної пазухи у вигляді клітин Галера (RR2,45; 95 \% CI-1,16-3,74) і перегородок (RR-3; 95 \% CI-1,72-4,28). Жоден із чинників не збільшував ймовірності розвитку у хворого на ХПС (табл. 2).

\section{Висновки}

1. У групі практично здорових осіб при проведенні комп'ютерної томографії пазух затемнення верхньощелепної пазухи виявлено в $25 \%$, решітчастих клітин - у $10 \%$.

2. Анатомічні особливості будови носової порожнини і навколоносових пазух (клітини Галера, перегородки верхньощелепних пазух, зміни гачкоподібного відростка, викривлення носової перегородки) виявлені у 63,89 \% обстежуваних. Жодна 3 вивчених особливостей не збільшувала ризик розвитку хронічного поліпозного процесу в навколоносових пазухах. Натомість клітини Галера, перегородки верхньощелепних пазух, подвоєний, аномально викривлений або гіпертрофований гачкоподібний відросток виявилися чинниками ризику розвитку в пацієнта хронічного ексудативного синуситу. Викривлення носової перегородки не збільшувало ймовірності розвитку хронічного запального процесу в навколоносових пазухах.

Перспективи подальших досліджень. Визначення чинників ризику розвитку хронічних синуситів дозволить розробити комплекс реабілітаційних заходів і покращити ефективність профілактики хворих із хронічними синуситами.

\section{Література}

1. Флетчер Р. Клиническая эпидемиология. Основы доказательной медицины / Р. Флетчер, С. Флетчер, Э. Вагнер; пер. с англ. Ю.Б. Шевелева. - М.: МедиаСфера, 3-е изд., 2004. - 352 с., ил.

2. Халафян A.A. Statistica 6. Статистический анализ данных. 3-е изд. Учебник / А.А. Халафян. - М.: ООО «Бином-Пресс», 2007. - 512 с.,ил.

3. A study of adherence to the AAO-HNS "Clinical Practice Guideline: Adult Sinusitis" / I. Darrat, K.Yaremchuk, S.Payne, M.Nelson // Ear Nose Throat J. - 2014. Vol. 93 (8). - P. 338-352.

4. Endoscopic, radiological, and symptom correlation of olfactory dysfunction in pre- and postsurgical patients of chronic rhinosinusitis / D. Gupta, A. Gulati, I. Singh [et al.] // Chem Senses. - 2014. - Vol. 39 (8). - P. 705-710.

5. Evaluation of airway hyperresponsiveness in chronic rhinosinusitis: values of sinus computed tomography / F. Chen, X. Luo, R. Xu [et al.] // Ann. Allergy Asthma Immunol. - 2014. - Vol. 113 (6). - P. 609-613.

6. International study of the incidence of particular types of septal deformities in chronic rhinosinusitis patients: the outcomes from five countries / C. Cingi, M.N. Bayar, M. Acar [et al.] // Am. J. Rhinol Allergy. - 2014, Sep-Oct. - Vol. 28 (5). - P. 404-413.

7. Tiwari R. Study of Anatomical Variations on CT in Chronic Sinusitis / R. Tiwari, R. Goyal // Indian J. Otolaryngol. Head Neck Surg. - 2015. - Vol. 67 (1). - P. 18-20.

\section{АНАТОМИЧЕСКИЕ ВАРИАНТЫ СТРОЕНИЯ ПОЛОСТИ НОСА И ОКОЛОНОСОВЫХ ПАЗУХ У БОЛЬНЫХ ХРОНИЧЕСКИМИ СИНУСИТАМИ}

\section{С.А. Левицкая}

Резюме. Проведен анализ результатов компьютерной томографии околоносовых пазух у 84 больных хроническим экссудативным синуситом, 72 - хроническим полипозным синуситом. Контрольная группа состояла из 20 практически здоровых людей. Анатомические особенности строения носовой полости и околоносовых пазух (клетки Галера, перегородки верхнечелюстных синусов, изменения крючковидного отростка, искривления носовой перегородки) выявлены у 63,89 \% исследуемых. Ни один из анатомических вариантов не увеличивал риск развития полипозного синусита. Клетки Галера (RR-2,45; 95 \% CI-1,16-3,74), перегородки верхнечелюстных пазух (RR-3; $95 \% \mathrm{CI}-1,72-4,28)$, аномалии развития крючковидного отростка (RR-3617; $95 \% \mathrm{CI}-1,62-4,72)$ увеличивали риск развития хронического экссудативного синусита.

Ключевые слова: хронические синуситы, факторы риска, анатомические особенности.

\section{ANATOMICAL VARIANTS OF NASAL CAVITY AND PARANASAL SINUSES STRUCTURE IN PATIENTS WITH CHRONIC SINUSITIS}

\section{S.A. Levytska}

Abstract. The analysis of the results of computer tomography of paranasal sinuses has been studied in 84 patients with chronic exudative sinusitis and 72 patients with nasal polyps. The control group consisted of 20 healthy individuals. The anatomical variants of the structure of the nasal cavity and paranasal sinuses (Galer cells, septa of maxillary sinuses, changes of uncinatus process, nasal septum deviation) were detected in $63.89 \%$ of surveyed. None of anatomical variants increase $d$ the risk of polypous sinusitis. Galer cells (RR-2,45; $95 \%$ CI-1,16-3,74), septa of maxillary sinus (RR-3; $95 \%$ CI-1,72-4,28), changes of uncinatus process (RR- 3,17; $95 \%$ CI-1,62-4,72) increased risk of chronic exudative sinusitis.

Key words: chronic sinusitis, risk factors, anatomical peculiarities.

Higher State Educational Institution of Ukraine "Bukovinian State Medical University" (Chernivtsi)

Рецензент - проф. Б.Г. Макар

(c) С.А. Левицька, 2015
Buk. Med. Herald. - 2015. - Vol. 19, № 4 (76). - P. 97-99

Надійшла до редакції 19.06.2015 року 